\title{
JAPAN'S DECLINING POPULATION AND DEMOGRAPHIC CHALLENGES
}

\section{Rajaram Panda}

\begin{abstract}
Japan is sitting on a demographic time bomb. The declining birth rate because of changing societal and economic factors impacting on priorities in human lives, and accentuated by a rapidly growing population poses a new challenge to policy makers. The governmental responses have been inadequate and need to be seriously addressed in the interests of the future of the country. Other Asian countries in the path of modernisation and fast economic growth are also falling into such trap. Like in the economic development Japan was the leader that led to the faster growth in other Asian countries, Japan ought to emerge as the new leader in addressing this demographic challenge so that other Asian countries could emulate Japan's example.
\end{abstract}

Keywords: Population, Birth rate, demography, immigration policy, projection, future scenario

Resumo: O Japão está sentado em uma bomba-relógio demográfica. A taxa de natalidade em declínio, por causa de fatores sociais e econômicos graças às rápidas transformações que impactam as prioridades na vida humana, e acentuada por uma população em rápido envelhecimento representa um novo desafio para os que decidem e executam políticas. As respostas governamentais têm sido inadequadas e devem ser seriamente abordadas em função dos interesses do país e de seu futuro. Outros países asiáticos, no caminho da modernização e crescimento econômico rápido, também estão caindo em tal armadilha. Como o Japão foi o líder no desenvolvimento econômico, que levou ao crescimento mais rápido em outros países asiáticos, o Japão deveria emergir como o novo líder na abordagem deste desafio demográfico para que outros países asiáticos possam emular o exemplo do Japão.

Palavras-chave: população, taxa de natalidade, demografia, política de imigração, projeção, cenário futuro.

1 Professor (Dr.) Panda is currently Indian Council for Cultural Relations India Chair Visiting Professor at Reitaku University, JAPAN. Disclaimer: The views expressed are author's own and do not represent either of the ICCR or the Government of India. E-mail: rajaram. panda@gmail.com. The manuscript is an expanded version of a lecture delivered by the author at the University of Sao Paulo, Brazil on August 18, 2017. 


\section{Introduction}

Japan is sitting on a demographic time bomb. As an inevitable consequence of modernisation fuelled by rapid economic growth during the post-War years, Japan has emerged as one the first few countries in Asia to face a new challenge of a declining population. This unprecedented population challenge threatens the nation with serious social, economic and political consequences whose impact is going to be felt for years to come. There have been several studies around the world on the issue of declining fertility of Japanese women, the real reason behind the declining trend in the nation's population. Not only it is not at the replacement level, even the existing rate continues to show declining trend. This is at the core of this challenge.

The past and the present governments have taken several measures to correct this worrying trend but since birth or the issue of having or not having a child is an individual choice, no government measures howsoever attractive by offering incentives have been of any help to address this issue.

\section{Post-War situation}

Japan's population scenario is directly linked with its progress to economic growth. In the immediate post-War years, Japan remained a relatively protected economy while benefiting from the liberalised external economies. Its liberalisation process was slow but soon fast tracked when outside pressures, particularly from the US, built up. While fostering the modern economy, Japan benefited from a growing workforce from the post-war baby boom period, whose energy contributed to the economic growth. With support from the government and backed by a competent bureaucracy, Japan's private sector performed impressively and was able to compete with the best in the world.

Japan's impressive economic performance that witnessed high growth led its manufacturing industry gradually to move up the value chain as it accrued capital and skilled workers. From labour-intensive industry such as textile that benefited from cheap labour available domestically in plenty, the economy moved up to more capitalintensive sectors such as steel and automobiles and further to highly skilled machinery and electronic manufacturing.

The first major challenge came when the Plaza Accord of 1985 made the country's exports less competitive as until then Japanese Yen was perceived as undervalued. The sustained high growth of the 1960s and 1970s unleashed by the Income Doubling Plan engineered by architect Okita Saburo left Japan flush with surplus capital that its exports had yielded and enabled Japan to rise up through the world's GDP ranking from seventh place in 1960 to second place in $1990 .^{2}$ While the economy continued to boom with multinational giants such as Honda, Toyota, Sony, Suzuki and others revolutionizing the

2 "Trade Profile: Japan Adopts to its Ageing Population" 6 June 2017, https://worldview.stratfor.com/ article/trade-profile-japan-adapts-its-aging-population?utm_campaign=LL_Content_Digest\&utm source $=$ hs_email\&utm_medium $=$ email\&utm_content $=52802197 \&$ _hse 
global automobile and electronic markets, domestic economy remained sluggish. The focus shifted to transfer labour and capital-intensive industries to overseas locations and Japan started focusing on high-tech industries. However, agriculture sector remained protected, rendering it non-competitive. There are cultural as well as political reasons for such a policy, which is beyond the scope of this paper. Suffice to say is that Japanese government finds compelling reason to protect this sector even now as only 12 per cent of the country's land is arable and fertile, the rest covering with mountains and therefore has to be retained.

Japan soon found itself confronted with complaint from competing firms in Europe and the US that while it is benefiting from a liberal economy of the world, it maintains a number of non-tariff barriers, such as prohibitive regulations on foreign ownership of shares among Japanese companies. Thus Japan's export economy became a victim of its own success when it was forced by its economic partners to impose voluntary export restraints and led to the Plaza Accord in 1985, which led to appreciate yen quickly, making Japanese exports uncompetitive. In the meantime, Japan had succeeded in spinning the web of international supply chains that has acquired the global norm today. Japan graduated from an export powerhouse to an investment powerhouse.

This growth story had greatly impacted the population pyramid as the accumulation of wealth in the hands of the Japanese people had started to change their life style. Japan which had experienced a baby boom immediately after World War-II, started facing demographic challenges as the country started showing declining trend in its population. In fact, compared to other Western countries, the population surge in Japan started earlier and ended sooner too. As a result, Japan today leads the world in demographic aging. Japan has now the peculiar distinction of having the world's oldest population since 2005. The number of persons retiring from the workforce is faster than younger ones joining. In this new situation, a capital-heavy country Japan now finds itself confronting with this new challenge and seeks to find ways to come out from the sluggish economy. Japan now looks for ways to accommodate the seniors in the competitive environment in a new trade strategy, whose direction does not look promising.

\section{Current Problem}

Broadly, Japan's current problems are two-fold: rapidly aging population and declining population. Forces that are responsible for this are declining fertility rates and lengthening of life spans. A total fertility rate of 2.1 would keep a population stable, even without migration. Japan reached this level in 1960 and after the baby boom period, has been falling persistently below since 1975 . The total fertility rate reached a low of 1.26 in 2005 but has risen to 1.44 at present, still not enough to arrest the declining trend. Child birth out of wedlock is stigmatised and therefore all babies are born within 
marriage only but the decline is a combination of delayed marriage, or not marrying at all, resulting in reduced fertility. Added to this problem is Japanese people are having a longer life span. According to World Bank data, Japanese women attained the longest life expectancy among 228 countries in 1982, and have held that position till today. As per past trend, a baby girl born in Japan in 2008 could expect to live till 86 . The male counterparts too achieved the longest life distinction in 1974 and can expect to live till 79. Over the years, the average life expectancy has risen to be longer.

There is something peculiar in this trend, which demographers call a health-survival paradox: Men seem to be healthier than women, but they die younger. Women tend to survive even with poor health compared to men. This means delay in physical decline in the case of women. Women represent $86 \%$ of Japanese over 100. In 2007, there were more than 32,000 centenarians; by 2030 , the projection is 10 times larger. This means more elderly women would be in need of assistance and medical care than elderly men.

\section{Dismal Projections}

In April 2017, a government-affiliated research institute in Japan made the projection that Japan's population is expected to fall below 100 million in 2053 and further plunge to 88.08 million in 2065, marking a 30 per cent fall from the 2015 level of 127.09 million. This projection is a bit better because the earlier projection five years ago had estimated the population to have shrunk to 81 million in 2065 . Though the revised estimate presents a better picture, the picture is grim over a longer period, with national population projected to plummet to just 51 million by 2115 , or about $60 \%$ of today's total. The announcement by the Health, Labour and Welfare Ministry's National Institute of Population and Social Security Research confirms that depopulation, which started in 2008 after Japan's population peaked at 128.08 million, was to stay as years pass by. The Institute therefore urged the government to prepare for consequences in wide-ranging areas, including the pension and health care systems. ${ }^{3}$ The past trends and the policy measures thus far suggest that this fate is unlikely to be altered in a major way. ${ }^{4}$

As regards the average life expectancy, it would increase to 84.95 years for men and 91.35 years for women by 2065 , from 80.75 years for men and 86.98 years for women in 2015. According to the latest estimate of the Institute, people 65 or older will account for 38.4 per cent of the total population in 2065, a rise from 26.6 per cent in

3 "Population Projection for Japan: 2016-2065, (April 2017)", National Institute of Population and Social Security Research, Tokyo, http://www.ipss.go.jp/site-ad/index_english/ population-e.html

4 Brad Glosserman, “A respite, not a reprieve, for Japan's demographic woes”, 20 April 2017, https://www.aspistrategist.org.au/respite-not-reprieve-japans-demographic-woes/?utm medium $=$ email\&utm_campaign $=$ Weekly $\% 20$ The $\% 20$ Strategist\&utm_content $=$ Weekly $\% 2 \overline{0}$ The $\% 20$ Strategist $+\mathrm{CID}$ 
2015. As regards the nation's total fertility rate, or the average number of children one woman is expected to give birth to in her lifetime, it would be 1.44 in 2065 , slighter higher than 1.35 projected for 2065 in the previous 2015 estimates. It is projected to dip to 1.42 in 2024 before rising to 1.44 in 2065 . This shows that the number of women in their $30 \mathrm{~s}$ or $40 \mathrm{~s}$ who get married or have babies would increase.

The estimate in the birth rate would mean Japan's population would drop below 100-million-threshold five years later than what was projected in the previous estimate in 2015. It is unlikely that the government could achieve its goal of maintaining a population of 100 million into the 2060s. The estimate suggests that Japan is having difficulty halting the acute population decline and the rapid aging of society.

Based on the census results, the government announces long-term population projections every five years, based on the number of births, deaths and cross-border moves of people. These are basic materials, which help the government to work on the design of the country's social security system, which includes the pension and health care systems.

In the age category of between zero and 14 , the number is estimated at 8.98 million in 2065, down from 15.95 million in 2015, with the share of this group in Japan's total population falling to 10.2 per cent from 12.5 per cent. The number of people aged between 15 and 64, the productive population category, is also expected to fall to 45.29 million from 77.28 million in 2015 , with their share sliding to 51.4 per cent from 60.8 per cent.

In the estimate, the elderly population would be 33.81 million, almost unchanged from the 2015 estimate. This estimate means that each elderly person will be supported by 1.3 people in the productive age group in 2065, down sharply from 2.3 people in 2015.

\section{Record dip in Population}

The results of an annual demographic survey released by the Ministry of Health, Labour and Welfare in early June 2017 revealed more disturbing readings. It revealed that the population took a record dip as births fell below 1 million for the first time in 2016. The total fertility rate fell 0.01 point from the previous year to 1.44 . Japan needs a fertility rate of 2.07 in order to maintain its population. The birth of babies below less than 1 million was as against the death of 1.3 million people, recording the largest population decline since $1899 .^{5}$

The results revealed that a total of 976,979 babies were born in 2016, 28,698 less than the previous year, while the number of deaths rose to a post-War high of 1,307,765, resulting a record population decline of 330,786. Of Japan's 47 prefectures, only

5 "Births fall below 1 mil.", The Yimouri Shimbun, 2 June 2017. http://the-japan-news. com/news/article/0003737368; Also see, The Japan Times, 2 June 2017, http://www. japantimes.co.jp/news/2017/06/02/national/social-issues/population-took-record-dip2016-births-fell-1-million/\#.WTI9HmiGNPY 
Okinawa saw the number of births top that of deaths. The most common cause of death was cancer $(29 \%)$, heart diseases $(15 \%)$, and pneumonia (9\%). This reflected a drop in the number of women of childbearing age and if this trend continues, the government shall find it difficult to achieve its fertility rate target of 1.8 by the end of fiscal 2025 and its goal of maintaining the population at around 100 million people in 2060.

Since the period of baby boom in the 1970s, the population graph has shown a steady declining curve. During the baby boom period, more than 2 million babies were born annually. This number dropped below 1.5 million in 1984 and further to 1.1 million in 2005 . It was for the $10^{\text {th }}$ straight year, deaths outpaced births and net population decline continued to widen since 2005, first time since the end of World War II. The Chief Cabinet Secretary Yoshihide Suga admitted that the fall in the total fertility rate is a "serious problem" for Japan and that the government shall "launch measures to deal with the situation as a top priority issue". ${ }^{6}$

In the meantime, the number of centenarians continued to increase and reached 67,824 in September 2017, hitting a record high for the $47^{\text {th }}$ consecutive year. ${ }^{7}$ The data released by the Health, Labor and Welfare Ministry in a report before Respect for the Aged Day in September 2017 showed that the figure rose by 2,132 from the previous year. The number of people aged 100 or higher was 153 in the first survey of 1963 . It increased to 10,000 in 1998 and then surpassed 30,000 in 2007, before more than doubling to 67,824 within a decade. While the number of women crossing 100 increased by 2,102 , accounting for 88 per cent of the total, the number of men rose by 30 .

A survey released by the Internal Affairs Communication Ministry the same month was a pointer to the future scenario. This survey of September 2017 revealed that the number of people aged 65 or older stood at 35.14 million, accounting for 27.7 per cent of the nation's total population, with the number of people aged 90 or older reaching 2.06 million, exceeding 2 million for the first time ever. ${ }^{8}$ The share of elderly people in the total population of Japan is the highest among the G-7 nations. Italy came second with 23 per cent, 4.7 points lower than Japan. The US had the smallest share at 15.4 per cent.

\section{Impact on Japan's economic future and government's measures}

This declining trend is disturbing for the government as this is going to impact the nation's economic future and leading to social chaos. Prime Minister Abe Shinzo has made countering population worries one of his top priorities, aiming for a birth rate of 1.8 children per woman from the current 1.4 . Despite this worry and unlike many

6 Ibid.

7 "No of 100-year-olds sets record", The Yimouri Shimbun, 18 September 2017, http://thejapan-news.com/news/article/0003947478

8 "Number of elderly 90 years or older totals over 2 million for 1 st time", The Yimouri Shimbun, 18 September 2017, http://the-japan-news.com/news/article/0003947478 
other advanced countries where immigration makes up for declining birth rates, Japan remains reluctant to open its doors to large-scale immigration. There is a fear that Japan's racial purity could come under threat if liberal immigration laws open door for foreign migrants, leading to inter-cultural marriages and resulting in births of children out of mixed parentage. Children of mixed parentage are contemptuously called 'hafus'. In 2016, when Priyanka Yoshikawa, a 22-year-old born of an Indian father and a Japanese mother was crowned Miss World Japan, many in social media disapproved her selection as she was seen as half Japanese and questioned on the relevance of the beauty pageant.

The estimates put Japan at the forefront of the uncharted demographic territory, though many other industrial countries, including even Japan's neighbours South Korea and China are beginning to enter as well into this difficult terrain. Though the consequences of this demographic shift are going to hugely impact the nation's future in almost all spheres, predicting precisely the intensity is not easy. If the political leadership in Japan is serious to arrest the trend, a number of interventions are needed including political, cultural and economic parameters, besides opting for liberal immigration laws or create environment that could lead to robust fertility rates.

In order to support working mothers, the Abe government announced in late May 2017 that it would create 220,000 new day care spots, bringing the number of children on the waiting list for nurseries to zero by the end of fiscal 2020. Abe promised to add another 100,000 spots during fiscal 2010-2022, taking the total to 320,000 in the next five years. ${ }^{9}$ In one of Abe's key pillars of economic policy, empowering working mothers with a view to strengthen the dwindling workforce, day care facility is a key propeller as shortage of nursery facilities and staff deter many women to return to their careers after child birth.

The biggest obstacle to the day care problem is the shortage of nursery workers. Without decent wages, drawing nursery workers could be difficult and therefore besides relaxing workers certification rules, the wage aspect needs to be considered. Today, the average monthly base pay for nursery workers with recent hikes of 6,000 yen per month is 3.23 million yen, which is below the national average of all workers at 4.9 million yen. Also, focus needs to be made on the quality of care, not just quantity.

\section{Other costs to society}

The emergence of a large size of elderly population also leaves other worrying costs to the society. According to National Police Agency data released and reported widely in the Japanese media on 10 April 2017 revealed that more than a third of the murders, attempted murders and fatal assaults involving members of the same family in

9 Tomoko Otake, "Prime Minister Abe unveils government push to solve day care crunch", The Japan Times, 31 May 2017, http://www.japantimes.co.jp/news/2017/05/31/ national/prime-minister-abe-unveils-government-push-solve-day-care-crunch/\#. WS-uHGiGNPY 
2014, were motivated by "fear of the future", such as concerns about caring for elderly relatives or managing financial hardship. ${ }^{10}$ Parents were the most frequent victims, which indicate that sons and daughters are unable to cope with caring for their elderly parents and see them as burden. Given the life style and attitude of the younger segment of population, the sense of individualism and emerging identity crisis, such cases are likely to increase in the future. Yet, the government maintains strict regulations for the entry of overseas caregivers, thereby constraining the health care industry.

Most of the people who attacked their parents, though "very serious and overly hardworking", were at the same time isolated both mentally and socially. Being frustrated with life, parents are easy targets to vent their frustration and vulnerable to attacks, resulting in deaths.

More worrying is the estimate that by 2025 one out of five elderly people will be suffering from dementia. ${ }^{11}$ This would mean the burdens on people providing nursing care will drastically increase. The peoples suffering from dementia tend to feel isolated after being unable to find someone to talk to about their problems, and eventually end up killing themselves or killed by some family members. This is the tragic part of the society in modern Japan. Remedial measures are therefore urgently needed.

According to Professor Lynda Gratton of London Business School, life could be redesigned with a 3 -stage life plan and the government has a role in preparing a society of increasing longevity in which 100-years lives will no longer be unusual. According to her, in a society where people live longer lives, people will have to work longer than they do today and three conventional stages of lives need to be reoriented - full-time education, full-time work and full-time retirement. ${ }^{12}$ Such a proposal is as per Prime Minister Abe Shinzo's key policy measures for a "revolution in human resources development", which was also election campaign pledge for polls on 22 October 2017.

Gratton suggests people need new plans based on a so-called multistage life in which, for example, workers choose not to stay at the same company they joined when they were young, but to go back to university for fresh education. Because of the inevitability of people spending more years at work, they need to redesign their lives. This could enable people living for 100 years and above to work into their 70 s and 80 s. In their second stint at work, family relationships also would require redesigning, with husband and wife swap work between education and office in

10 "Intrafamily crime a reflection of Japan's aging society", The Japan Times, 10 April 2017, http:/www.japantimes.co.jp/news/2017/04/10/national/crime-legal/intrafamily-crimereflection-japans-aging-society/\#.WVGxeGiGNPY

11 "Stable Child, nursing care vital to spurring economy", The Yomiuri Shimbun, 17 February 2017, http://the-japan-news.com/news/article/0003516234

12 Etsuo Kono, "Increasing longevity means 3-stage life plan will change", The Yomiuri Shimbun, 13 September 2017. http://the-japan-news.com/news/article/0003938195 
order to keep the financial situation at home stable. This arrangement could be problematic as the percentage of women at work is relatively low compared with other developed countries than men, which is why Abe government's policy is to bring in more women to join the workforce. The culture of Japanese companies needs to be changed. The relevance of life-long learning is more now than earlier days as in the age of high-speed technological innovation, workers could gain additional skills through re-education, allowing them to do different things. As more and more developed countries are facing demographic challenges with declining birth rates and aged society, Japan can lead the world by adopting innovative policies and address the aging issue.

\section{Relaxing Immigration Laws?}

Japan is going to host the Olympics in 2020 and that would be a good time to have a rethink on the immigration issue as Japan would require extra labour force to cope with the daunting construction work and making other preparations to host this international event. But given the conservative attitude of Japan, the change is unlikely to happen. Even on the healthcare service sector where Japan is in urgent need of health care givers for catering to the needs of the aged, Japan has put stringent terms for the Filipino care givers, thereby restricting their numbers and making many ineligible.

However, it would be incorrect to see the issue entirely pessimistically. The government has put in place some corrective measures with a long term perspective to create a more liberal environment for people to accept presence of more foreigners in the society. The popular Jet Program (Japan Exchange and Teaching) at school level to create a large pool of English-speaking youth is one. Another is accepting certain number of women from some Asian countries, such as the Philippines, in the rural parts of Japan for the purpose of marrying men who find it difficult to get a wife among the native population. This way, a new situation could be created, leading to increased openness to immigration in the coming years. Though there is a sizable section of people in countries like Brazil and Peru who are of Japanese origin, they are unwilling to return to their country of origin as they are already well settled in services or other businesses and would not like disruption. Brazilians or Peruvians of Japanese descent also could face difficulties in adapting to the native Japanese culture as their culture and way of living are based on the countries of their adoption. Despite common facial features, they are likely to be seen disapprovingly and at times suspiciously by native Japanese who would be ignorant about their past but compare with themselves.

To put in perspective, the demographic time bomb that Japan is sitting on is because of low fertility combined with increased life expectancy, thereby creating a population structure that is significantly weighted towards older members of society. There are fewer people under 30 than there are between the ages of 30 
and 60 . When the middle-aged section of people grow old and die, there will be far fewer people remaining behind. To put it differently, the current middle-aged generation of Japanese has failed to replace itself.

Japan, therefore, needs to relook at its immigration laws and do more to assimilate foreigners and offset population decline. ${ }^{13}$ Interestingly, there is no enough debate in Japan on immigration, unlike in the US where immigration is always a hot topic for discussion. That Japan has a small foreign-born population compared to other countries is true but to say that Japan is a closed country would be wrong because Japan does not actually do much to keep out immigrants. Japan has no legal limits on either the number of people who can get work visas, the number of people who can get permanent residency, or the number who can become naturalised citizens. This stands in contrast to the US, which still imposes legal limits on immigration. Japan also does not require permanent residency as a prerequisite for becoming a naturalised citizen. Despite Japan having an unusually lax immigration controls, a relatively few foreigners have chosen to move there, which is the reason for Japan's low immigration levels. It is just that language and cultural barriers deter immigrants make Japan as their choice country to move in. This is interpreted as immigration controls. However, neither Japanese leaders nor its people seem prepared to deal with the flow of newcomers in a proactive way. The Japanese government seems to avoid adopting an immigration policy unpopular with the public. The bottom line is accepting immigrants could be the ultimate key to reviving Japan. ${ }^{14}$

The Abe government created a new post of Minister of State for the Promotion of Overcoming Population Decline and Vitalizing Local Economy and an enormous budget was allocated to address the serious issue of population decline. The progress has been effectively zero. The government is afraid that addressing the issue of immigration would be extremely unpopular among the Japanese public which has an extremely negative image of the word "immigration" for fear that a massive influx of foreigners unable to speak Japanese would disrupt Japan's domestic harmonious society. The increase in the number of Chinese immigrants is already a matter of concern

\section{Factors behind Decline and consequences}

The reasons why such is the case is not difficult to identify. Less noticed but closely linked to low fertility rate are other factors such as increased education of women, delayed marriage, economic opportunities for women, the fear of increased financial burden in modern, urban societies, etc. Even in case of marriages, if both the man and woman are working, they do not want to have babies for lack of child

13 Noah Smith, "How Japan needs to change to welcome immigrants", 4 September 2017, https://www. bloomberg.com/view/articles/2017-09-03/how-japan-needs-to-change-to-welcome-immigrants

14 Toshihiro Menju, "Accepting Immigrants is the Ultimate Key to reviving Japan”, AJISS Commentary No. 248, http://www2.jiia.or.jp/en_commentary/201710/11-1.html 
support system at home when parents are out to office. This group of people belong to the category of Double-Income-No-Kids or DINKs. For others, when the marriageable age at some point of time gets over, many chose not to marry at all and lead a life of melancholy and suffer from stress-related diseases.

When they retire from service and grow old, loneliness leads to depression and many commit suicide. Such a situation has given rise to new areas of study such as how to handle grief, death, loneliness etc. As a result old-age homes have mushroomed all over Japan, with cases of dementia increasing. Because of few children, in the medical science paediatric as a branch of medical discipline has lost its lustre and not many students chose to specialise in this branch of study because of lack of demand. In the hospitals, paediatric wards have disappeared because few children are brought for treatment. Places that were meant for play school for kids are converted into offices for making funeral arrangement. In malls, corners meant for kids to play when parents go for shopping are being converted for aged people to relax and spend some time over coffee. One can find tables in restaurants meant for one person occupied by single either man or woman after office enjoying a beer and food as no one would be waiting at home and they do not know what to do when return home early. Japan may be a modern and advanced society but it still remains conservative in many ways. For example, childbirth out of wedlock is stigmatised, which is why the decision not to marry also means that one has chosen not to have children.

\section{More Women joining work force}

Interestingly, owing to the shortage of labour, the government is trying to create situation whereby more women are drawn into the country's labour force. Normally, a woman who is working and finds a husband chooses to leave the job after giving birth to a child and take up domestic responsibility solely. The modern woman is unwilling to surrender the freedom to remain independent, which is why marriage is not an option. Child care centres close to office arranged by the employer if a woman chooses to continue to work, is found inconvenient. Women face social pressures to manage a career while also raising a family. The responsibility usually falls on the woman as balancing work with child-rearing because there are not enough nursery schools to look after their infants, leaving them with no choice than to quit the job. This also puts financial constraint on the family.

A government survey of people between the ages of 18 and 34 in 2011 showed that over $61 \%$ of unmarried men among those surveyed lacked a girlfriend and 49.5 unmarried women boyfriends. The same survey showed that $49 \%$ of women found no need to marry, while $45 \%$ of men showed no interest in dating the opposite sex. This shows that there are also attitudinal issues in the Japanese society towards life. Some surveys done recently also show that the percentage of young people losing interest in having sex is increasing. 


\section{Changing attitude}

In recent times, there are signs of change in attitude towards marriage or romance in certain age category of Japanese people but this does not address to the population issue, though such a trend could address to issues of melancholy, loneliness, depression and so on. There are reports that a growing number of Japanese in their late $40 \mathrm{~s}$ and early 50 s are being driven by a desire for a romantic relationship. ${ }^{15}$ This could be a positive sign but for women in this age category who may have crossed the child bearing age and attained menopause, entering into a matrimonial alliance does not address to the declining population issue. This age category of people lived through the asset-inflated bubble economy and now looks for companionship amidst economic uncertainties.

According to the National Institute of Population and Social Security Research, this is a developing trend as the number of men between 50 and 54 who entered nuptials for the first time in 2015 was 4.7 times higher than in 1990 at 2,950. The ratio for women meanwhile doubled to 1,169. In the same age category, the number of men who embarked on their second marriage scored better at 7,710, or 1.7 times higher than in 1990, while women seeking second marriages more than doubled to 6,222. The reason given by men for such late decision was that they had no time to meet women outside of work and once they reach a senior position in office, are reluctant to seek partners in the office itself because either the female colleagues could be too young to be proposed or for fear of losing face, besides non-availability of female colleagues suitable for marriage in terms of age. This category of people entering wedlock do not have to worry for kids as they have passed that stage and therefore do not have to worry about added expense of raising a child.

Decline in births would mean shortage of labour force and this would negatively impact the sluggish economy. As there is little interest in liberalising the strict immigration laws to bring in foreign labour, there are some who propose to invest more in robotics as a means to address the conflict of a shortfall of labour with the need for workers. But can a country survive by depending only on technology? Japan would find it difficult to answer to this question.

According to the demographic statistic estimate released by the Health, Labour and Welfare Ministry in December 2016, the annual number of births in the country dipped below one million at 981,000 in 2016, the lowest since 1899, the first time since records became available. This is worrying for Japan.

The declining in population is going to impact more severely on Japan's economic future more than now, and impact the social security system, a mechanism by which the fruit of a nation's economic growth is distributed through tax and insurance systems.

15 "Bubble-generation singles give middle-age marriage a shot", The Japan Times, 4 June 2017, http://www.japantimes.co.jp/news/2017/06/04/national/bubble-generation-singles-givemiddle-age-marriage-shot/\#.WTP_3Gh95PY 
Japan shall find it hard to meet the social security needs of the people without growth, and without wealth distribution through social security, steady growth cannot be achieved. Japan needs to notice warning signal in the social security and growth cycle matrix.

\section{Lesson for the world}

Japan's experience can be a lesson for the rest of the Asian countries on high economic growth path so that they can take corrective measures before they too face a similar situation such as Japan's rapidly ageing society. The International Monetary Fund has urged the Asian economies to learn from Japan's experience and act early to cope with rapidly ageing populations. It warned that if they do not do that, they would run the risk of "getting old before becoming rich". ${ }^{16}$

During the post War years, many Asian counties reaped demographic dividends, with the number of working population growing faster than the number of dependents. A strong economic policy with a favourable demographic structure was instrumental to Asia's high growth rate. This dividend is no longer sustainable and thus throws new challenges with significant implications. ${ }^{17}$

Viewed in the larger context, Asia finds itself in a heterogeneous stage of aging with countries such as Japan, South Korea and Singapore are already old age societies, while India and Indonesia enjoy demographic dividends with a younger population. In this population dynamics where countries becoming old before becoming rich has become a common phenomenon, can countries such as India and Indonesia escape such a fate in the future that Japan, South Korea and Singapore face at the moment? As regards China, by imposing the "One Child" policy and kept it enforced for few decades, China denied itself some 350+ million people and has only delayed the inevitable process of having an aged society sooner than it would have been. However, both India and China with large populations will be able to cope with the challenge of a situation when the economies are in sound footings even while there is a large size of aged population to be taken care of. The existence of some semblance of family values that have withstood the onslaught of a new culture unleashed by modernisation could provide a balm to a society that it never wanted to emerge. The future of Asia appears therefore bleak but the positivity too should not be discounted. An aging society could have its own shine too.

The IMF study says that the population growth rate is projected to fall to zero for Asia by 2050 and the share of working-age people, now at its peak, will decline over the coming decades. It further says that the share of the population aged 65 and older

16 "IMF warns Asia to learn from Japan's experience, act early on rapidly ageing populations", The Japan Times, 9 May 2017, http://www.japantimes.co.jp/news/2017/05/09/business/imfwarns-asia-learn-japans-experience-act-early-rapidly-aging-population/\#.WRJ5i4h95PY

17 International Monetary Fund, http:/www.imf.org/en/News/Articles/2017/05/10/tr050917-transcriptof-asia-pacific-regional-economic-outlook-press-conference?cid=em-COM-123-35207 
will increase rapidly and reach close to two and half times the current level by 2050 . This population change can be more pronounced in Japan which is already facing both an ageing and shrinking population. In order to address this issue, governments ought to prioritise measures to induct more females and elderly persons into the workforce as well as revamping social safety nets.

The IMF Managing Director Christine Lagarde warned at a conference in Seoul in September 2017 that ageing populations in key Asian economies will drag on their growth and therefore urged policymakers to step up their responses to shifting demographics. Following Japan as the first "ultra-aged" country would be countries such as China, Korea and Thailand impacting at an average drop of 1 per cent in the growth rate. Slower growth rate would have significant knock-on effects around the world. The task before the political leaders in Asia is gigantic and some regional response could be the next logical step. 